\title{
Double filicide for extended suicide (frustrated) of a subject with major psychotic depression and dependent personality disorder
}

\section{Doble filicidio por suicidio prolongado (frustrado) de un sujeto con depresión psicótica mayor y trastorno de personalidad dependiente}

\author{
DOI: $10.46932 / \mathrm{sfjdv2n3-057}$
}

Received in: May 1st, 2021

Accepted in: Jun 30th, 2021

\author{
Dr. Bernat-Noël Tiffon Nonis \\ Universitat Abad Oliba-CEU. Calle de Bellesguard, no30. 08022 Barcelona (Spain). \\ E-mail: btiffonn@uao.es
}

\begin{abstract}
:
A case of frustrated extended suicide is illustrated, where the perpetrator can't commit her own suicide, but having perpetrated the murder of her own 2 children due to suffering from a severe major depressive disorder with psychotic symptoms and dependent personality traits. The case is illustrated with the psychometric tests administered and also, the forensic psychometry of the case is analyzed.
\end{abstract}

Keywords: Expanded Suicide, Murder, Major Psychotic Depressive Disorder, Personality Disorder, Filicide, Criminal.

\section{RESUMEN:}

Se ilustra un caso de suicidio ampliado frustrado, en el que la autora no puede suicidarse, pero ha perpetrado el asesinato de sus propios 2 hijos debido a que padece un trastorno depresivo mayor grave con síntomas psicóticos y rasgos de personalidad dependiente. El caso se ilustra con las pruebas psicométricas administradas y además, se analiza la psicometría forense del caso.

Palabras clave: Suicidio ampliado, Asesinato, Trastorno depresivo mayor psicótico, Trastorno de la personalidad, Filicidio, Criminal.

\section{INTRODUCTION}

In general terms, there are few or no research studies and/or psychological evaluation techniques regarding the predictive capacity of aggressive behavior of the scope of an extended suicide (Tiffon y González-Fernández, 2021). So when a father or a mother kills their own child, it is known as filicide. This criminological situation always causes a great social, legal, and media impact (Tiffon, 2017, 2021a).

The word "filicide" comes from the Latin filuis, son, and caedére, to kill, and designates the death of one's own son by the father or mother. When one of the parents kills their newborn baby, they commit a homicide that is labeled as infanticide. The word "filicide" comes from the Latin filuis, son, and caedére, to kill, and designates the death of one's own son by the father or mother. When one of the parents kills their newborn baby, they commit a homicide that is labeled infanticide. In general, filicide is reserved for 
children with age ranges between 1 to 18 years, being subdivided into early-type when it includes the ages of 1 to 12 years and late-type when more than 13 years (Estupiñán et al.; 2016; Tiffon, 2017 and Tiffon y González-Fernández, 2021b).

In general terms, in blood crimes perpetrated by subjects with pathological impulsivity, there are no conditions for an attenuation of the sentence, if there is no other type of mental disorder of a serious nature (Tiffon and González-Fernández, 2021b). In the present case, the informed person presents such affective disorder, but it does not reach or have a modifying circumstance for criminal responsibility of notorious importance for the Spanish judicial system. However, there is a psychotic component in her major depressive disorder that affects her cognitive and/or volitional abilities, so the content of the psychotic-delusional thought must be contextualized within the limits of what is possible, with sufficient coherence to be shown acceptable. Although this phenomenon does not exclude the male sex, it tends to be more frequent among the female population (Tiffon, 2021b).

\section{THE CASE}

This is a woman from South America, about 30 years old, separated, and mother of two children who, at the time of the death of the minors, were 11 and 9 years old. The purpose of the report was to assess the psychic and mental status of the informed and establish a relationship of retrospective compatibility of her behavior at the time of perpetrating the sad events. The victimizer suffered from major depressive disorder and presented basic personality traits of a dependent type; likewise, she went through a series of adverse psychosocial factors that aggravated her mood and psycho-emotional state and that aggravated her basic psychopathological condition, for which she decided to murder her two children in a pathological context of extended suicide; in this case, frustrated by being rescued by the figure of her ex-husband. The iter criminis perpetrated was subjecting the minors to the ingestion of central nervous system depressant pills in order to put them to sleep, and then proceed to drown them in the bathtub of her home. The informed person presented an acute and critical psycho-emotional alteration prior to the commission of the event, as a result of the precursor events that she experienced as damaging against her person and her physical integrity (Tiffon, 2021c). In light of the above, criminal-criminological behavior was the product of a set of basic psychopathological factors (added to adverse psychosocial factors) that acted as prior conditioning factors in the previously described behavioral materialization (Tiffon, 2021d).

The chronology of events: the same day that the sad events are committed, the informed person is admitted to the Emergency Service of a Hospital in Barcelona and remains for 3 days before proceeding to enter the Penitentiary Center. After 3 days of her admission to the hospital, she is explored by the Forensic Doctors and then, she is transferred and admitted to the Acute Unit of the Penitentiary Psychiatric 
Hospital Unit (PPHU) of the Penitentiary Center. She will remain there for 3 months, to be later transferred to the Women's Penitentiary Center.

\section{THE METHOD}

To prepare this case, the following sources of information were used:

1. Clinical-expert interviews with the informed woman kept in the Women's Penitentiary Center for 3 days.

2. Interview with the brother of the informed.

3. Telephone interviews with a friend of the person informed.

4. Psychopathological and psychometric study: MMPI-2, MCMI-III, Salamanca screening Test, 16 PF-5, Personality Assessment Inventory - PAI, Hamilton Rating Scale for Depression HRSD-, State-Trait Anxiety Inventory -State-Trait Anxiety Inventory, STAI-, Hamilton Anxiety Rating Scale -HARS-, Beck Hopelessness Scale -Hopelessness Scale, HS-, Plutchik Suicide Risk Scale -Risk of Suicide, RS-, Scale for Suicide Ideation (Scale for Suicide Ideation, SSI).

5. Study of the clinical-legal documentation provided (Psychiatric Report of the Penitentiary Psychiatric Hospitalization Unit -PPHU- and Medical-Forensic Report).

\section{RESULTS}

The results obtained from the different psychological and psychopathological tests administered are compatible with the existence of a mood disorder: Major Depressive Disorder of severe intensity with psychotic symptoms and suicidal tendency (see clinically and statistically significant scores on the scales of depressive disorders and psychotic features of MCMI-III and PAI).

Likewise, the scores also suggest the existence of dependent personality disorder (see clinically and statistically significant scores on the scales of depressive disorders and psychotic traits of the MCMIIII, the PAI, and the 16 PF-5). 
Figure 1: Results and psychological and psychopathological profile of the report obtained from the Millon Clinical Multiaxial Inventory (MCMI-III, version 3 of the year 2005).

\section{P Pearson}

\section{INVENTARIO CLÍNICO MULTIAXIAL DE MILLON-III}

VALIDEZ $=0 \quad$ INCONSISTENCIA $=7$

CÓDIGO DE PERSONALIDAD: - " $12 \mathrm{~A} 2 \mathrm{~B} \times \underline{37} 8 \mathrm{~B} 6 \mathrm{~A}+8 \mathrm{~A} 6 \mathrm{~B}$ " $54 / /$ - $^{\mathrm{*}}$ - * $/ /$

CÓDIGO DE SÍNDROME: A " D H " $/ /$ - " CC PP * $/ /$

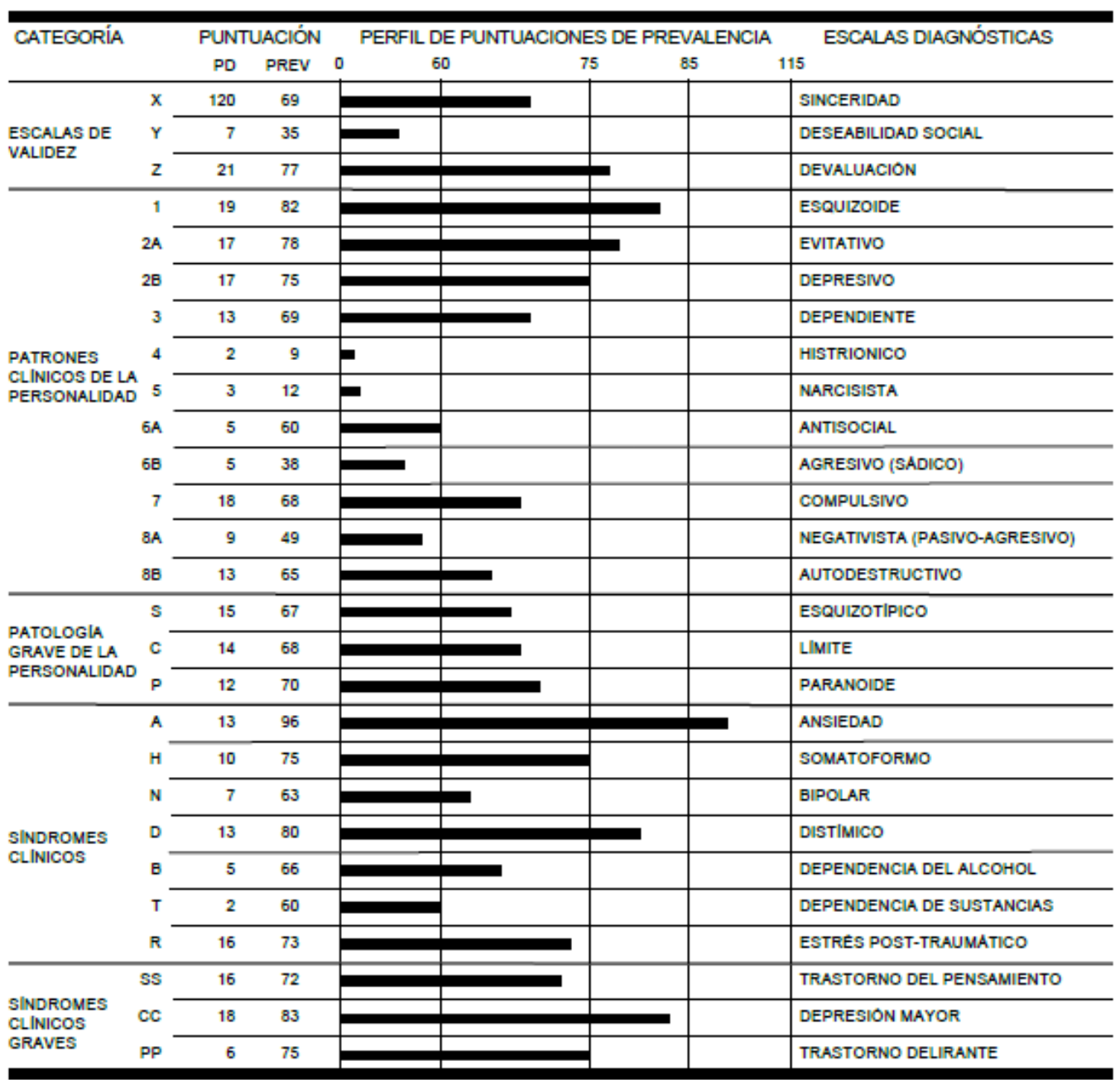

Figure 2a: Results and psychological and psychopathological profile of the report obtained from the Personality Assessment Inventory (PAI) by Morey (2011).

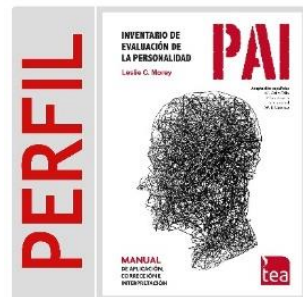




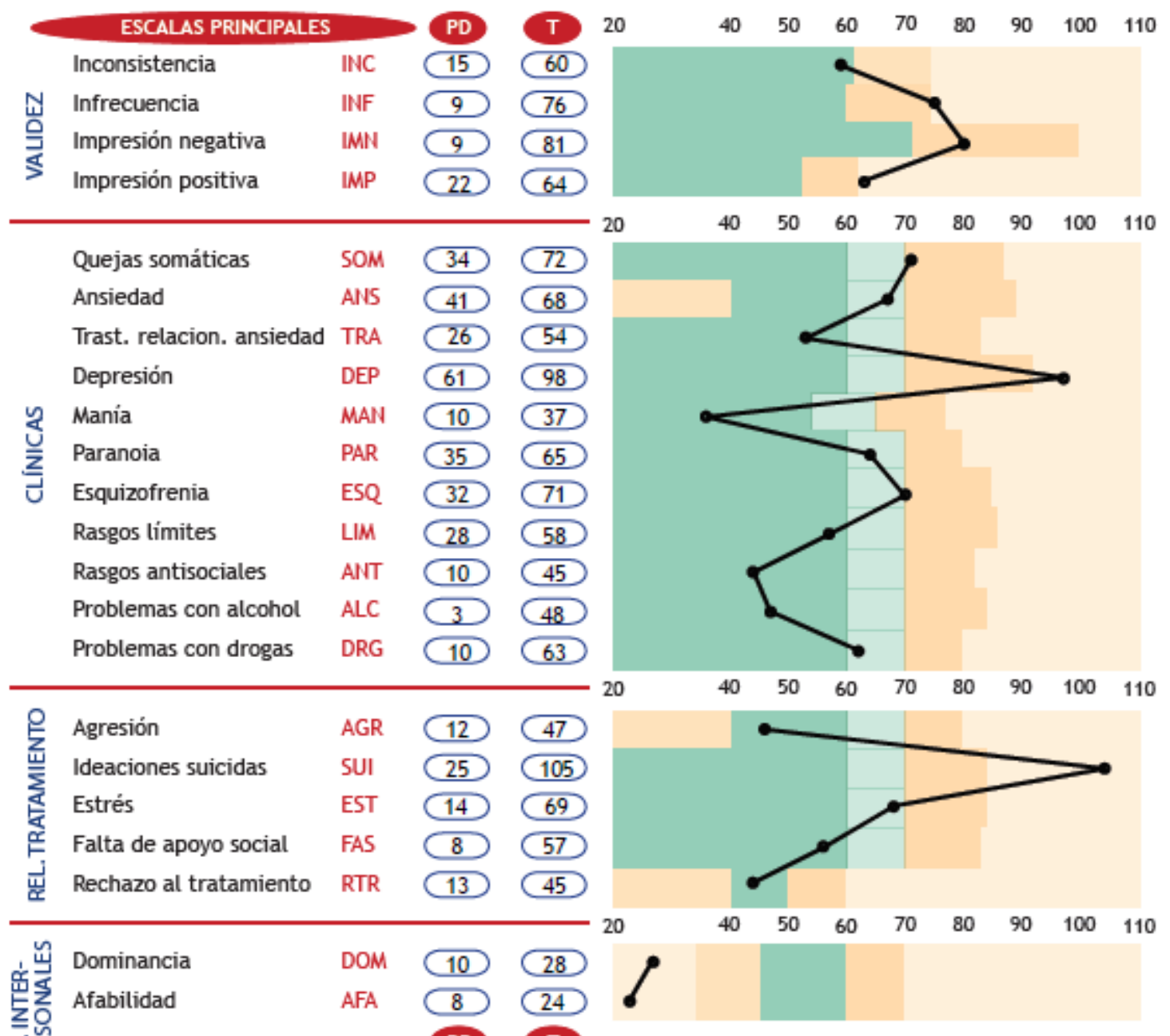

PD $T$ 
Figure 2b: Results and psychological and psychopathological profile of the report obtained from the Personality Assessment Inventory (PAI) by Morey (2011).

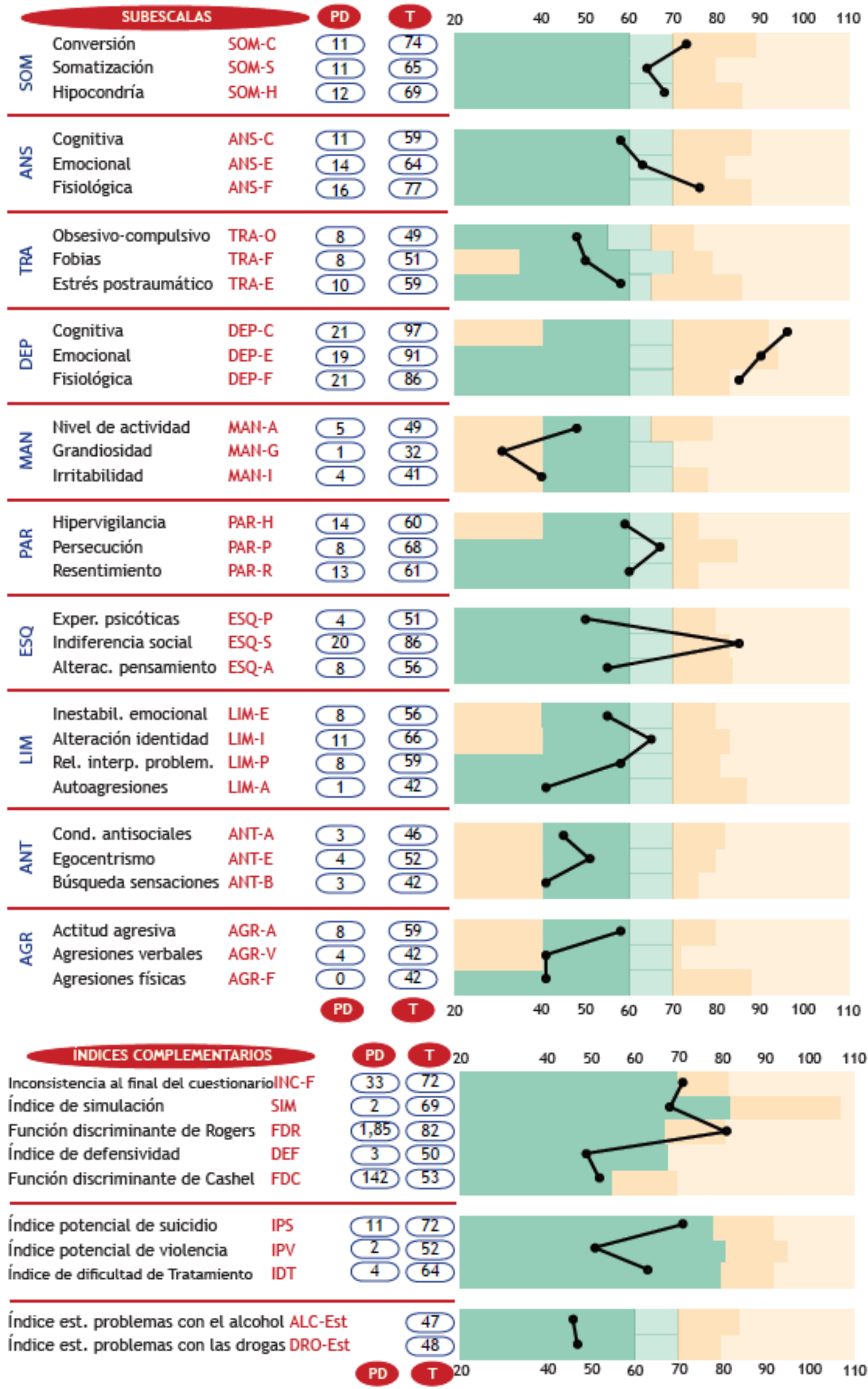


Figure 3: Results and psychological profile of the report obtained from Cattell's 16 Personality Factors (16PF) (1995).

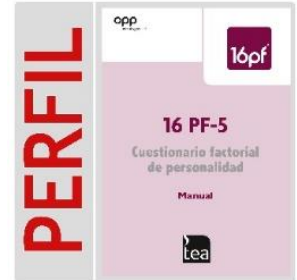

\section{ESCALAS PRIMARIAS}

$\begin{array}{ll}\text { A } & \text { Afabilidad } \\ \text { B } & \text { Razonamiento } \\ \text { C } & \text { Estabilidad } \\ \text { E } & \text { Dominancia } \\ \text { F } & \text { Animación } \\ \text { G } & \text { Atención a las normas } \\ \text { H } & \text { Atrevimiento } \\ \text { I } & \text { Sensibilidad } \\ \text { L } & \text { Vigilancia } \\ \text { M } & \text { Abstracción } \\ \text { N } & \text { Privacidad } \\ \text { O } & \text { Aprensión } \\ \text { Q1 } & \text { Apertura al cambio } \\ \text { Q2 } & \text { Autosuficiencia } \\ \text { Q3 } & \text { Perfeccionismo } \\ \text { Q4 } & \text { Tensión }\end{array}$

ESTILOS DE RESPUESTA

MI Manipulación de la imagen

IN Infrecuencia

$\mathrm{AQ}$ Aquiescencia

DIMENSIONES GLOBALES

Ext Extraversión
Ans Ansiedad
Dur Dureza
Ind Independencia
AuC Auto-control
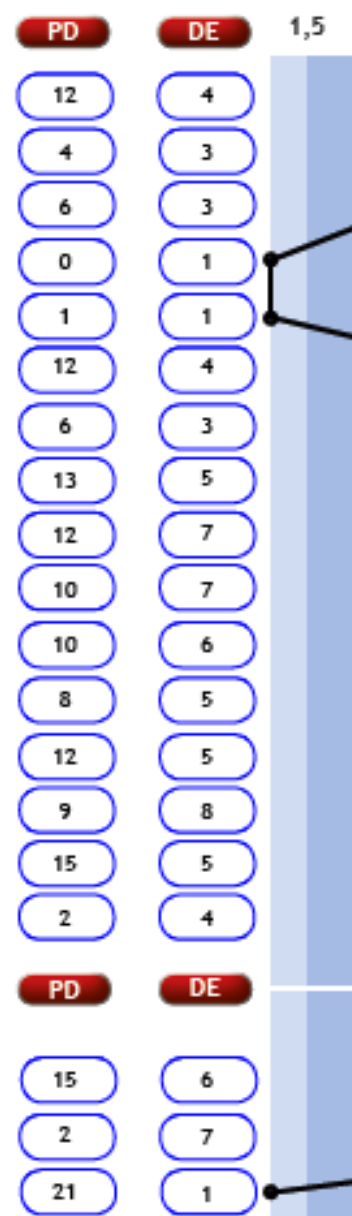

21

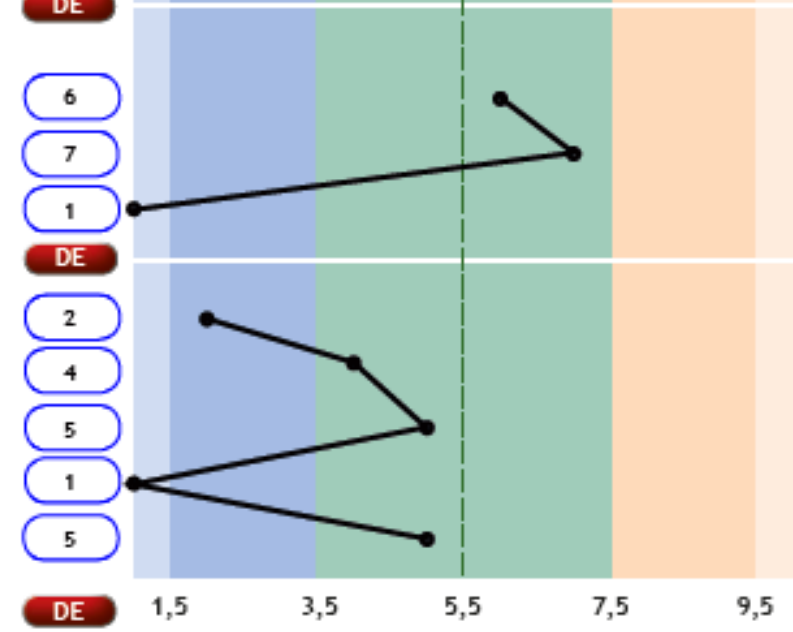




\section{DISCUSSION}

According to the clinical documentation close to the perpetration of the events, the informed person is compatible with the fact that, at the time of the frustrated extended suicide, she presented:

A. Major Depressive Disorder of Severe intensity (ICD-10-CA code F32.31).

B. Dependent Personality Disorder (ICD-10-CA code F60.7).

The reported experienced a series of adverse psychosocial factors, such as:

A. The experience of physical and verbal abuse received by her spouse continuously, as well as threats.

B. Economic precariousness due to her inability to rejoin the labor market, needing the help of social and religious services.

C. Impossibility of returning to the country of origin due to a difficult financial situation and given the need for medical-surgical treatment of his eldest daughter, suffering from bone dysplasia

D. Fear of losing custody of her children given the situation of high psychosocial conflict concerning her ex-husband and the inability to achieve job and economic stability.

About the alleged facts in the proceedings, the informed presents a character structure characterized by the existence of personality traits based on emotional dependence, low self-esteem, and submission; these came to fracture and aggravate psycho-emotionally presenting a situation of vulnerability to the emotional pathology, intervening in a continuous and interrelated way the stressors and external adverse factors mentioned above (serious family, economic and work problems), developing a Serious Mixed Anxious-Depressive Adaptive Disorder that progressively evolved incubating -at the same time- into a Major Depressive Disorder of Severe intensity with psychotic symptoms.

As a co-morbidity factor (concomitance of several pathologies), it should be noted that on the date of the events, she experienced a decompensation in the form of an acute emotional stress reaction, associated with drug intoxication with hypnotic-sedatives, with a clear effect on the higher cognitive functions, with predetermined autolytic intentionality, and with subsequent dissociative effects that do not facilitate the later memory of such events.

In this context described above, the alleged facts are compatible with a situation of extended suicide -as stated in the Emergency Assistance Report of a Hospital-, being in the present case frustrated, as it was not completed with the death of the intentional). 
The concatenation of the pathological factors described above came to determine a profound cognitive impairment during the materialization of the alleged facts in the proceedings. In this sense, it can be considered as compatible that the analytical-reflective and intellectual capacity was significant and highly affected by the cognitive distortion caused by the disorders described, aggravated by the ingestion and intoxication of psychotropic drugs that affected the consciousness of this and broke the inhibitory mechanisms of her behavior (Tiffon, 2017).

\section{CONCLUSIONS}

Patients suffering from depressive disorders and with thoughts of death or suicidal ideation have lower self-confidence, excessive dependence on others, and a high level of self-function compared to depressed patients without thoughts of death or suicide (Fountoulakis K., Iacovides A, Fotiou F, et al., 2004). For Joiner, Brown, and Wingate, (2005), lack of hope is a fundamental psychological correlate of suicide. A study on hopelessness has shown a stronger correlation between hopelessness, suicidal ideation, and suicide than, between hopelessness and depression, or depression and suicide.

In line with what has been previously described, the present case converges with what is described by the previously authors, so that subjects with major depressive disorder with personality traits suffering from psychotic-paranoid symptoms and who present a personality tendency of a dependent-avoidant type, tend to be more fragile or more vulnerable to psychosocial adversities, and therefore, to a tendency to suicidal thinking or behavior.

The fragility of their psycho-emotional state, already suffered by the previously psychopathological disorders, makes such group of subjects more sensitive or vulnerable (less resilient, depending on their degree of mental fragility) to stressful events. 


\section{REFERENCES}

- Cattell, R.B.; Cattell, A. K., Cattell, H.E.P. (1995). 16 PF-5. Cuestionario Factorial de Personalidad. TEA Ediciones. Madrid.

- $\quad$ Estupiñán Rodríguez N, Rodríguez Hernández E, Gallardo Sarmiento A, Jiménez Ramírez I, Bayona Santana DR, Villalonga Costa L. Filicidio: apuntes históricos y reflexión actual. revmedicaelectronica [Internet]. 2016 [citado 18 Jul 2021];; 38(3):[aprox. 7 p.]. Disponible en: http://revmedicaelectronica.sld.cu/index.php/rme/article/view/1480

- $\quad$ Fountoulakis K, Iacovides A, Fotiou F, et al. Neurobiological and psychological correlates of suicide attempts and thoughts of death in patients with major depression. Neuropsychobiology. 2004; 49:42-62

- $\quad$ Joiner, T.E.; Brown, J.S.; Wingate, L.R. The psychology and neurobiology of suicidal behavior. Annu. Rev. Psychol. 2005; 56:287-314.

- $\quad$ Millon, T.; Davis, R. y Millon, C. (2011 - [Ed. orig. TEA Ediciones, 2007]). «Inventario Clínico Multiaxial de Millon-III». Pearson Educación. Madrid.

- Morey, L.C. (2007). «PAI. Personality Assessment Inventory». Psychological Assessment Resources, Florida, EE.UU.

- $\quad$ Tiffon, B.-N. "Los Crímenes de Perejil” (2015). Bosch Editor. Barcelona.

- $\quad$ Tiffon, B.-N. “Archivos Delictivo-Criminológicos” (2016). Bosch Editor. Barcelona.

- Tiffon, B.-N. y cols. (2017). “Atlas de Psicología Forense (Penal)”. J.M. Bosch Editor. Barcelona.

- $\quad$ Tiffon, B.-N. y cols. (2019). “Atlas Práctico-Criminológico de Psicometría Forense (Volumen I): Asesinatos”. J.M. Bosch Editor. Barcelona.

- $\quad$ Tiffon, B.-N. y cols. (2019). “Atlas Práctico-Criminológico de Psicometría Forense (Volumen II): Tentativas de Asesinatos”. J.M. Bosch Editor. Barcelona.

- $\quad$ Tiffon, B.-N. y cols. (2020). "Atlas práctico-criminológico de psicometría forense (Volumen III: Parafilias y agresiones sexuales de adultos)”. J.M. Bosch Editor. Barcelona.

- $\quad$ Tiffon, B.-N. y cols. (2020). "Atlas práctico-criminológico de psicometría forense (Volumen IV: Parafilias y agresiones sexuales de menores)”. J.M. Bosch Editor. Barcelona. 
- $\quad$ Tiffon, B.-N. (2017). "A propósito de un caso de doble filicidio por suicidio ampliado frustrado”. Revista de Derecho y Proceso Penal, nº. 48, págs. 335-349.

- $\quad$ Tiffon, B.-N. \& González-Fernández $\left(2021^{\mathrm{a}}\right)$. "Desperation In Major Serious Depressive Disorders And Extended Suicide Risk: A Case Of Double Filicide". Asean Journal Of Psychiatry, Vol. 22(S2), June 2021: 1-5. Issn: 2231-7805

- $\quad$ Tiffon, B.-N. \& González-Fernández $\left(2021^{\mathrm{a}}\right)$. "Desperation In Major Serious Depressive Disorders And Extended Suicide Risk: A Case Of Double Filicide". Asean Journal Of Psychiatry, Vol. 22(S2), June 2021: 1-5. Issn: 2231-7791

- $\quad$ Tiffon, B.-N. \& González-Fernández (2021 $)$. "Amok Syndrome. Qualified Perspectives on an Aggressive Reaction of Pathological Impulsiveness in The Perpetration of a Double Crime with a Firearm". ASEAN Journal of Psychiatry, Vol. 22(S2), June 2021: 1-5 ISSN: 2231-7805

- $\quad$ Tiffon, B.-N. \& González-Fernández (2021 b). "Amok Syndrome. Qualified Perspectives on an Aggressive Reaction of Pathological Impulsiveness in The Perpetration of a Double Crime with a Firearm". ASEAN Journal of Psychiatry, Vol. 22(S2), June 2021: 1-5. ISSN: 2231-7791

- $\quad$ Tiffon, B.-N. (2021) $)^{\text {a }}$ "Criminal and Forensic Psychology of a Case of Filicide by Decapitation of a Minor". Journal of Forensic Medicine. Case Series. Volume 6:3. ISSN: 2472-1026

- $\quad$ Tiffon, B.-N- (2021) ${ }^{\mathrm{b}}$."Murder induced deliriously by a "folie à deux". Vol. 2 No. 2 (2021): South Florida Journal of Development, Miami, v. 2, n. 2, apr./jun. 2021 ISSN: 2675-5459 Págs. 3560-3564

DOI: https://doi.org/10.46932/sfjdv2n2-191

- $\quad$ Tiffon, B.-N. $(2021)^{\mathrm{c}}$. "Criminal personality in a trained elite military and assassination". Vol. 2 No. 2 (2021): South Florida Journal of Development, Miami, v. 2, n. 2, apr./jun. 2021 ISSN: 2675-5459 Págs. 3555-3559

DOI: https://doi.org/10.46932/sfjdv2n2-190

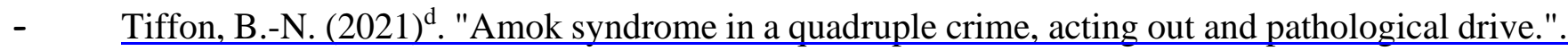
Vol. 2 No. 2 (2021): South Florida Journal of Development, Miami, v. 2, n. 2, apr./jun. 2021 ISSN: 2675$\underline{5459}$

DOI: https://doi.org/10.46932/sfjdv2n2-189

- $\quad$ Tiffon, B.-N. \& González-Fernández (2021). Cocaine Cravings, Borderline Personality Disorder \& Attempted Homicide ASEAN Journal of Psychiatry, Vol. 22(5), July 2021; 1-4.

- $\quad$ Tiffon B.-N. (2022). "Atlas of Forensic Criminal Psychology". Taylor \& Francis Group-CRC Press. USA. In press. 2022. 